\title{
Salute to you, Nanshan
}

\author{
Connie Chen, Guangqiao Zeng \\ Editorial Office, Journal of Thoracic Disease, Guangzhou, China \\ Correspondence to: Guangqiao Zeng. Editorial Office, Journal of Thoracic Disease, No. 151 Yanjiang Road, Guangzhou 510120, China. \\ Email: zgqiao@vip.163.com.
}

Submitted Sep 12, 2020. Accepted for publication Sep 17, 2020.

doi: 10.21037/jtd-2020-tdc-001

View this article at: http://dx.doi.org/10.21037/jtd-2020-tdc-001

September $10^{\text {th }}$ of 2020 saw the $36^{\text {th }}$ anniversary of Teacher's Day since its inception in China. On this memorable occasion, the editorial crew at Fournal of Thoracic Disease $(\mathcal{F T D})$ dedicated heartfelt respects to their Editor-in-Chief, Dr. Prof Nanshan Zhong, Laureate of Republic Medal and Academician of Chinese Academy of Engineering, for his great contribution to the Journal over so many years (Figure 1).

Chinese people have never forgotten the tough time and hardship they experienced in containing SARS coronavirus that swept the country in 2003. In 2013, 10 years after defeat of the SARS outbreak, Dr. Zhong organized a special issue of FTD, Emerging Infectious Respiratory Disease \& the $10^{\text {th }}$ Anniversary of SARS Epidemics, which covered the latest progress and hot topics on prevention of novel emerging respiratory infections including SARS, H5N1, H1N1 and H7N9, to command attention to lessons learnt from the past. Today, these valuable lessons have sustained China in winning the combat against COVID-19.

Amidst the pleasant minutes of face-to-face interview in his busy itinerary, Dr. Zhong inquired about the current situation of $\mathcal{F T D}$, and among others, the submission of articles related to COVID-19. Commenting on his article published in the March issue this year, Modified SEIR and AI prediction of the epidemics trend of COVID-19 in China under public health interventions, Zhong noted that the epidemic size in China predicted in this article is much smaller than as declared by certain foreign studies, but yet is most close to what happens in the real world. Majority of those prediction models, he added, actually work by putatively tracing the psychosocial behavior patterns of a naturally-occurring population. However sophisticated and intriguing they may seem, it has turned out that the prediction data about this country by various international teams, over-laden with arrogance and conceit, never succeed in estimating the dauntless valour of Chinese
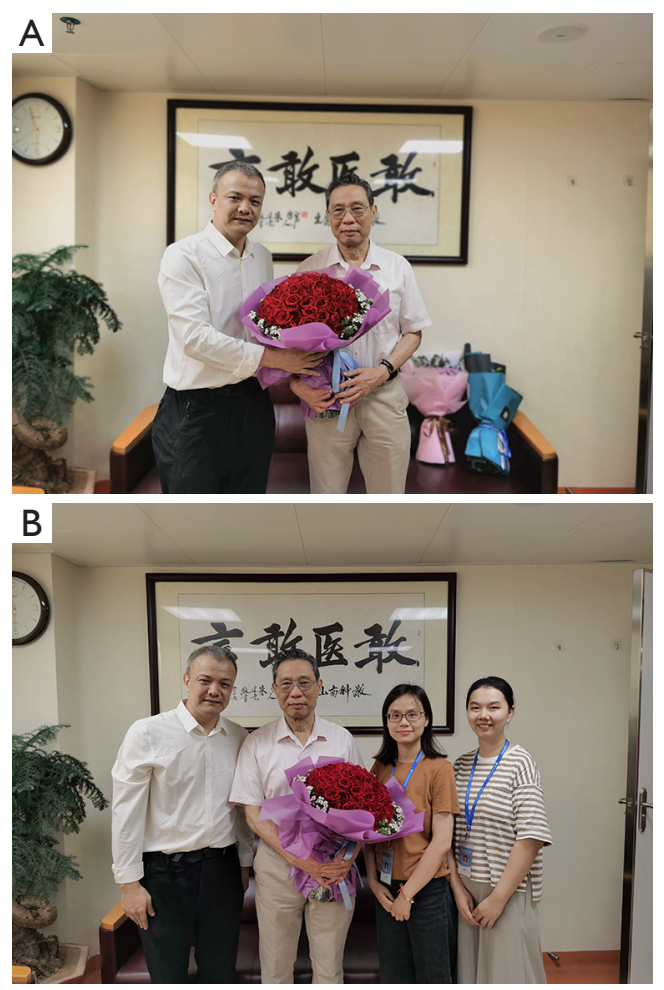

Figure 1 Journal of Thoracic Disease (FTD) editorial crew and Editor-in-Chief Nanshan Zhong.

people in fighting any invasions. "As with this journal, keep moving regardless of any difficulties, and never slow down because of the pandemic," he said while looking straight into our eyes.

With the strong support and encouragement from Dr. Zhong, FTD has yielded substantial progress toward its mission of disseminating edge-cutting findings in medical sciences pertinent to the journal scope. With even more diligence, we are determined to devote our career to the 
excellency of publication ethics and code of conduct. Thank you, Nanshan.

\section{Acknowledgments}

Funding: None.

\section{Footnote}

Provenance and Peer Review: This article was commissioned by the editorial office, Fournal of Thoracic Disease. The article did not undergo external peer review.

Conflicts of Interest: Both authors have completed the ICMJE uniform disclosure form (available at http://dx.doi. org/10.21037/jtd-2020-tdc-001). The authors have no

Cite this article as: Chen C, Zeng G. Salute to you, Nanshan. J Thorac Dis 2020;12(9):4596-4597. doi: 10.21037/jtd-2020tdc-001 conflicts of interest to declare.

Ethical Statement: The authors are accountable for all aspects of the work in ensuring that questions related to the accuracy or integrity of any part of the work are appropriately investigated and resolved.

Open Access Statement: This is an Open Access article distributed in accordance with the Creative Commons Attribution-NonCommercial-NoDerivs 4.0 International License (CC BY-NC-ND 4.0), which permits the noncommercial replication and distribution of the article with the strict proviso that no changes or edits are made and the original work is properly cited (including links to both the formal publication through the relevant DOI and the license). See: https://creativecommons.org/licenses/by-nc-nd/4.0/. 